\title{
PIM2 Gene
}

National Cancer Institute

\section{Source}

National Cancer Institute. PIM2 Gene. NCI Thesaurus. Code C104798.

This gene plays a role in protein phosphorylation, cell proliferation and the regulation of apoptosis. 